\title{
PENGARUH METODE PEMBELAJARAN EKLEKTIK TERHADAP HASIL BELAJAR BAHASA ARAB SISWA MADRASAH TSANAWIYAH MA'HAD HADITS AL-JUNAIDIYAH BIRU BONE
}

\author{
A. Fajar Awaluddin \\ fajarandizaki82@yahoo.com \\ Institut Agama Islam Negeri (IAIN) Bone
}

\begin{abstract}
This research aims to know the effect of learning method toward the students' Arabic achievement in the fifth grade of Islamic Junior High School (Madrasah Tsanawiyah) Al-Junaidiyah Biru Bone for academic year 2017/2018. The research questions were: is there any difference in Arabic learning achievement as a whole between a group of students who have been given intiqâiyyah methods and another group of students who have been given conventional methods. This research was an experimental study using randomized control group design. The influencing factorial variable is learning methods on Arabic. The Arabic learning achievement was used to know the students" skill or capability Arabic learning. In experimental class, intiqâiyyah methods as experiment methods, and conventional methods as control methods. This research concluded that there was any difference between students Arabic achievements of group of students who have been given intiqâiyyah methods and group of students who have been given conventional methods.
\end{abstract}

Keywords: eclectic method, conventional method, Arabic learning achievement

\section{PENDAHULUAN}

Pembelajaran bahasa Arab di MTs Al-Junaidiyah Biru Bone tahun pelajaran 2017/2018 belum menggembirakan. Bahasa Arab masih merupakan materi yang menjadi momok bagi sebagian siswa. Hasil belajar siswa berada pada posisi urutan terbawah dibandingkan dengan pelajaran-pelajaran lainnya. Pada tahun ajaran 2017/2018, rerata hasil 
Evaluasi Hasil Belajar (EHB) siswa yang diambil secara random pada kelas VII saja, untuk bahasa Arab 55.9. Adapun materi lainnya berada di atasnya: Qur'an Hadits 82.5, Aqidah Akhlak 76.7, Fiqh 65.3, Sejarah Kebudayaan Islam 72.5, PKN 83.6, Bahasa Indonesia 73.5, Matematika 63.1, IPA 67.3, IPS 72.5, KTS 81.6, PENJAS 76.4, Bahasa Inggris 63.7 dan Komputer 82.3, ini merupakan kenyataan bahwa pembelajaran bahasa Arab masih perlu dicarikan solusi alternatif ( Daya Serap EHB Madrasah Tsanawiyah Ma'had Hadits Al-Junaidiyah Biru Bone).

Data menyebutkan bahwa rerata Hasil Belajar Bahasa Arab tiga tahun terakhir dapat dilihat pada tabel berikut ini ( Daya Serap EHB Madrasah Tsanawiyah Ma'had Hadits AlJunaidiyah Biru Bone):

Tabel 1. Hasil Murni Belajar Bahasa Arab Siswa MTs Al-Junaidiyah Biru Bone 2015/2016 - 2017/2018

\begin{tabular}{cccc}
\hline No & Tahun Ajaran & Rata-rata Nilai Bahasa & KKM \\
\hline 1. & $2015 / 2016$ & 7 & 75 \\
2. & $2016 / 2017$ & 7 & 75 \\
3. & $2018 / 2019$ & 7 & 75 \\
\hline & Rata-Rata & 72.73 & 75 \\
\hline
\end{tabular}

Masalah tersebut menarik karena Madrasah Tsanawiyah Ma'had Hadits AlJunaidiyah Biru Bone ini adalah madrasah yang berada di bawah naungan Pondok Pesantren Modern Al-Junaidiyah Biru Bone yang notabenenya lebih banyak mempelajari pelajaran-pelajaran agama termasuk bahasa Arab. Madrasah ini pula telah banyak memperoleh prestasi di bidang bahasa Arab diantaranya: Pada tahun 2015 mewakili Sulawesi Selatan pidato bahasa Arab di cabang Lomba pidato bahasa Arab di ajang AKSIOMA Kemenag 2015. Pada tahun 2016 juga memperoleh juara pidato bahasa Arab Tingkat Kabupaten Bone dalam ajang AKSIOMA Kemenag.( Prestasi Madrasah Tsanawiyah Ma'had Hadits Al-Junaidiyah Biru Bone).

Dengan keberadaan Madrasah Tsanawiyah Ma'had Hadits Al-Junaidiyah Biru Bone sebagai Madrasah swasta yang menyandang status "DISAMAKAN", maka diasumsikan Pembelajaran Bahasa Arabnya pun merupakan pionir bagi madrasah lainnya. Pembelajaran Bahasa Arab menjadi model pembelajaran di Madrasah Tsanawiyah lainnya di Kabupaten Bone. Jika Madrasah Tsanawiyah Ma'had Hadits Al-Junaidiyah Biru Bone saja masih kurang berhasil dalam pembelajaran bahasa Arab, apalagi madrasah lainnya, bahasa Arab 
adalah materi yang belum mencapai hasil yang betul-betul menggembirakan dan selalu berada pada level bawah.

Ada banyak indikasi yang menyebabkan kenapa bahasa Arab di Madrasah saat ini masih berada pada level terbawah dibandingkan dengan materi pelajaran lainnya. Ada paradigma bahwa bahasa Arab kurang penting, karena saat ini, bahasa yang dipakai dalam percaturan dunia nomor satunya adalah bahasa Inggris. Para orang tua, sebagiannya menganggap, bahwa materi bahasa Arab tidak terlalu penting, sehingga dukungan mereka akan anak-anaknya kurang dibandingkan dengan materi lainnya.

Sebagai contoh, bahasa Inggris, dulu mungkin dianggap materi yang susah, namun saat ini asumsi itu sudah hilang. Orang menganggap anak usia SD/MI bias lancar berbahasa Inggris bukan suatu hal yang luar biasa, biasa-biasa saja. Itu disebabkan perhatian dan dukungan keluarga atau orang tua sangat kuat.

Kesulitan pembelajaran bahasa Arab pun terjadi tidak hanya di Madrasah Tsanawiyah Ma'had Hadits Al-Junaidiyah Biru Bone, namun di hampir semua level pendidikan yang memasukkan bahasa Arab sebagai bagian dari kurikulumnya. Di STAIN Watampone saja terutama jurusan-jurusan yang non-agama, rerata peserta didik menganggap bahwa bahasa Arab itu susah dan menjelimet lebih parahnya lagi ada yang merasa ketakutan untuk menghadpi kuliah bahasa Arab.

Pembelajaran bahasa Arab di Madrasah Tsanawiyah memiliki tujuan: Pertama, Mengembangkan kemampuan berkomunikasi dalam bahasa Arab, baik lisan maupun tulis yang mencakup empat kecakapan berbahasa, yakni menyimak (istima"), berbicara (kalam), membaca (qira'ah), dan menulis (kitabah). Kedua, Menumbuhkan kesadaran tentang pentingnya bahasa Arab sebagai salah satu bahasa asing untuk menjadi alat utama belajar, khususnya dalam mengkaji sumber-sumber ajaran Islam. Ketiga, Mengembangkan pemahaman tentang saling keterkaitan antara bahasa dan budaya serta memperluas cakrawala budaya. Dengan demikian, peserta didik diharapkan memiliki wawasan lintas budaya dan melibatkan diri dalam keragaman budaya (Wahab, 2008:1).

Untuk mencapai target pembelajaran yang diharapkan, harus didukung oleh berbagai faktor sehingga pembelajaran bahasa Arab akan memberhasilkan dan menyenangkan.

Di antara faktor-faktor yang menyebabkan keberhasilan pembelajaran termasuk pembelajaran bahasa Arab adalah guru, bahan ajar, media, sarana prasarana, lingkungan belajar, motivasi siswa, jenis evaluasi yang digunakan dan lain sebagainya. 
Dari paparan diatas penulis telah meneliti hasil belajar bahasa Arab tersebut, ditinjau dari aspek metode pembelajaran yang digunakan terhadap belajar bahasa Arab siswa Madrasah Tsanawiyah Ma'had Hadits Al-Junaidiyah Biru Bone pada semester ganjil tahun ajaran 2017/2018. Permasalahan penelitian yang akan dijawab adalah "Apakah terdapat perbedaan hasil belajar bahasa Arab antara siswa yang diperlakukan dengan menggunakan metode intiqâiiyyah dengan yang menggunakan metode konvensional? Hipotesisny adalah "Hasil belajar bahasa Arab siswa yang dibelajarkan dengan metode intiqâiyyah lebih tinggi daripada siswa yang diberi metode konvensional”.

Adapun yang menjadi pokok pembahasan dalam makalah ini yaitu apakah itu model pembelajaran eklektik serta sejauh mana pengaruh model pembelajaran eklektik terhadap hasil belajar bahasa Arab siswa Madrasah Tsanawiyah Ma'had Hadits Al-Junaidiyah Biru Bone?

\section{A. Metode Pembelajaran Bahasa Arab}

Ibnu khaldun berkata, "Sesungguhnya pengajaran itu merupakan profesi yang membutuhkan pengetahuan, keterampilan, dan kecermatan karena ia sama halnya dengan pelatihan kecakapan yang memerlukan kiat, strategi dan ketelatenan, sehingga menjadi cakap dan professional (B. Suryosubroto, 1997:15). Penerapan metode pengajaran tidak akan berjalan dengan efektif dan efisien sebagai media pengantar materi pengajaran bila penerapannya tanpa didasari dengan pengetahuan yang memadai tentang metode itu. Sehingga metode bisa saja akan menjadi penghambat jalannya proses pengajaran, bukan komponen yang menunjang pencapaian tujuan, jika tidak tepat aplikasinya. Oleh karena itu, penting sekali untuk memahami dengan baik dan benar tentang karakteristik suatu metode (Yamin, 2005:127).

Secara sederhana, metode pengajaran bahasa Arab dapat digolongkan menjadi dua macam, yaitu: pertama, metode tradisional/klasikal dan kedua, metode modern. Metode pengajaran bahasa Arab tradisional adalah metode pengajaran bahasa Arab yang terfokus pada "bahasa sebagai budaya ilmu" sehingga belajar bahasa Arab berarti belajar secara mendalam tentang seluk-beluk ilmu bahasa Arab, baik aspek gramatika/sintaksis (Qowaid nahwu), morfem atau morfologi (Qowaid as-sharf) ataupun sastra (adab). Metode yang berkembang dan masyhur digunakan untuk tujuan tersebut adalah Metode qowaid dan tarjamah. Metode tersebut mampu bertahan beberapa abad, bahkan sampai sekarang pesantren-pesantren di Indonesia, khususnya pesantren salafiyah masih menerapkan metode 
tersebut. Hal ini didasarkan pada hal-hal sebagai berikut: Pertama, tujuan pengajaran bahasa arab tampaknya pada aspek budaya/ilmu, terutama nahwu dan ilmu sharaf. Kedua kemampuan ilmu nahwu dianggap sebagai syarat mutlak sebagai alat untuk memahami teks atau kata bahasa Arab klasik yang tidak memakai harakat, dan tanda baca lainnya. Ketiga, bidang tersebut merupakan tradisi turun temurun, sehingga kemampuan di bidang itu memberikan "rasa percaya diri (gengsi) tersendiri di kalangan mereka".

Secara sederhana, metode pengajaran bahasa Arab dapat digolongkan menjadi dua macam, yaitu: pertama, metode tradisional/klasikal dan kedua, metode modern. Metode pengajaran bahasa Arab tradisional adalah metode pengajaran bahasa Arab yang terfokus pada "bahasa sebagai budaya ilmu" sehingga belajar bahasa Arab berarti belajar secara mendalam tentang seluk-beluk ilmu bahasa Arab, baik aspek gramatika/sintaksis (Qowaid nahwu), morfem atau morfologi (Qowaid as-sharf) ataupun sastra (adab). Metode yang berkembang dan masyhur digunakan untuk tujuan tersebut adalah Metode qowaid dan tarjamah. Metode tersebut mampu bertahan beberapa abad, bahkan sampai sekarang pesantren-pesantren di Indonesia, khususnya pesantren salafiyah masih menerapkan metode tersebut. Hal ini didasarkan pada hal-hal sebagai berikut: Pertama, tujuan pengajaran bahasa arab tampaknya pada aspek budaya/ilmu, terutama nahwu dan ilmu sharaf. Kedua kemampuan ilmu nahwu dianggap sebagai syarat mutlak sebagai alat untuk memahami teks atau kata bahasa Arab klasik yang tidak memakai harakat, dan tanda baca lainnya. Ketiga, bidang tersebut merupakan tradisi turun temurun, sehingga kemampuan di bidang itu memberikan "rasa percaya diri (gengsi) tersendiri di kalangan mereka".

Metode pengajaran bahasa Arab modern adalah metode pengajaran yang berorientasi pada tujuan bahasa sebagai alat. Artinya, bahasa Arab dipandang sebagai alat komunikasi dalam kehidupan modern, sehingga inti belajar bahasa Arab adalah kemampuan untuk menggunakan bahasa tersebut secara aktif dan mampu memahami ucapa atau ungkapan dalam bahasa Arab. Metode yang lazim digunakan dalam pengajarannya adalah metode langsung (tariiqah al - mubasysyarah). Munculnya metode ini didasari pada asumsi bahwa bahasa adalah sesuatu yang hidup, oleh karena itu harus dikomunikasikan dan dilatih terus sebagaimana anak kecil belajar bahasa.

\section{Macam- Macam Metode Pembelajaran}

Metode pembelajaran atau metode mengajar merupakan salah satu cara yang digunakan guru dalam mengadakan hubungan dengan siswa saat berlangsungnya pengajaran. Dalam metode pengajaran seorang guru diharapkan untuk bisa menhidupkan 
suasana kelas atau menumbuh kegiatan belajar siswa. Tugas guru yaitu memilih metode yang tepat untuk menciptakan proses pembelajaran yang baik. Menurut Nana Sujana metode pembelajaran yang baik yaitu, metode pembelaran yang bervariasi atau kombinasi dari beberapa metode pembelajaran. Seperti penggabungan metode ceramah dengan tanya jawab dan tugas, ceramah diskusi dan tugas (Suryosubroto, 1997:15).

Adapun macam-macam metode pembelajaran yaitu:

a. Metode Ceramah

Metode ceramah yaitu metode yang digunakan seorang guru, yang mana guru menyampaikan hal-hal menarik antusias siswa untuk belajar. Sedangkan seorang murid hanya menjadi pendengar aktif. Metode ceramah terkadang menjadi metode yang kurang efektif sebab siswa hanya dituntut mendengar. Kurang adanya pola komunikasi antar murid dan guru. Seperti yang dikemukakan Winarno Surachmad M. Ed,yang dimaksud metode ceramah sebagai metode pengajaran ialah penerangan dan penuturan secara lisan oleh guru terhadap kelasnya. Selama berlangsungnya ceramah, guru bisa menggunakan alat-alat pembantu seperti gambar-gambar bagan, agar uraian metode jadi lebih jelas. Tetapi metode utama dalam perhubungan guru dengan murid-muridnya adala berbicara.

b. Metode Tanya Jawab

Metode tanya jawab atau metode komunikasi antar guru dan murid dengan guru mempertanyakan kepada murid berkenan dengan materi-materi sebelumnya pernah dibahas, dan murid menjawab pertanyaan guru atau sebaliknya guru menjawab pertanyaan murid. (Yamin, 2005:67) Metode ini baik digunakan untuk mengulas pelajar yang telah lalu. Ini metode sangat penting dalam pembelajaran. Manakala murid lupa dengan pembelajaran lalu dengan proses tanya jawab murid akan mengingat-ngingat pembelajaran lalu.

\section{c. Metode Diskusi}

Merupakan interaksi antara siswa dengan siswa atau siswa dengan guru untuk menganalisis, memecahkan masalah, menggali atau memperdbatkan topik permasalahan tertentu.

d. Metode Pembelajaran Terprogram

Metode pembelajaran terprogram identik dengan menggunakan bahan pengajaran yang sudah disiapkan secara khusus. Metode ini berbasis pada spesifikasi bahasan dengan patokan pada bahan khusus untuk memperinci matari pembelajaran, yang 
dengan ini para siswa mendapatkan kebebasan penuh untuk belajar sesuai dengan kecepatan pemahamannya masing-masing. Metode ini baik digunakan apabila kurang mendapatkan interaksi sosial, pembelajaran formal, mempermudah siswa belajar dalam waktu yang diinginkan.

Dari paparan di atas dapat disimpulkan bahwa, jenis metode pembelajaran bahasa Arab ada dua; metode umum seperti metode-metode yang digunakan dalam semua materi pembelajaran dan metode khusus, yang hanya digunakan pada pembelajaran bahasa Arab. Di antara metode tersebut adalah; metode Qawâ"id dan Terjemah (قبرط دعاوقلا قبمزنلو), metode

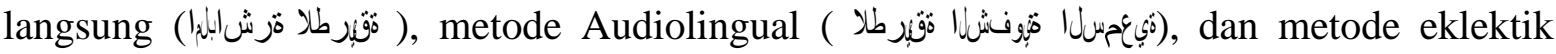

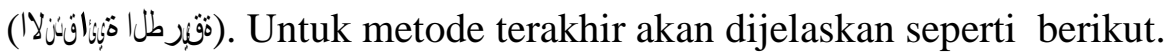

\section{B. Metode Intiqâiyyah (Eklektik)}

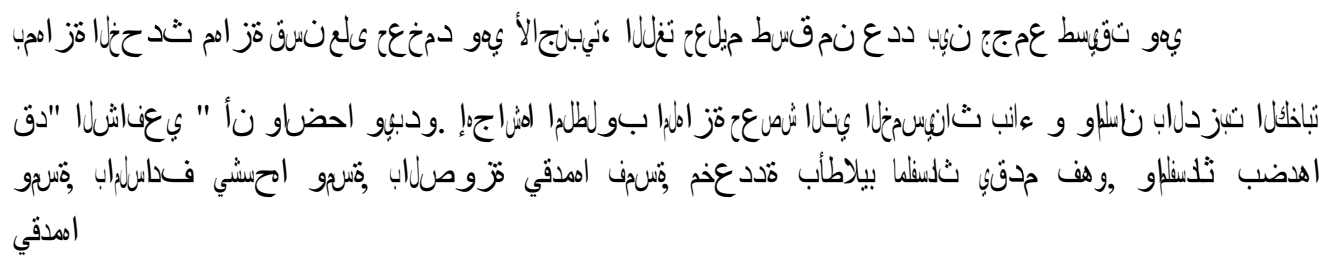

(Walîd al-Anâtî, 1430 H/2009 M)

Metode eklektik artinya gabungan atau kombinasi; cara menyajikan bahan pelajaran bahasa Arab melalui macam-macam metode, sehingga proses pembelajaran lebih banyak ditekankan pada kemahiran bercakap-cakap, menulis, membaca dan memahami pengertianpengertian tertentu. Metode eklektik adalah metode pilihan dan gabungan dari dua metode atau lebih.

Eklektik adalah istilah yang kadang-kadang digunakan bagi praktek pemakaian ciriciri beberapa metode yang berbeda dalam pengajaran bahasa. Metode eklektik, mengandung arti pemilihan dan penggabungan. Di dalam bahasa Arab, metode ini disebut dengan beberapa nama, antara lain, Thariqah al-Intiqo'iyyah ( الطريقة اللإنتقائية ), Mukhtarah ( الطريقة (الطريقة التوفيقية (الطريقة المزدوجة (المختارة), Mazdujah). Taufiqiyyah Perlu ditegaskan bahwa penggabungan metode-metode ini hanya bisa dilakukan antar metode yang sehaluan (Sanjaya, 2010:126-127).

Paparan di atas dapat disimpulkan bahwa yang dimaksud dengan metode eklektik adalah metode yang menggabungkan metode terjemah dan kaidah, metode langsung dan metode mendengar dan mengucapkan menjadi bagian yang tidak akan terpisahkan karena bahasa Arab tidak akan terlepas dari empat kemahiran bahasa; menyimak (istim/â"), 
berbicara (kalâm), membaca (qirâ'ah), dan menulis (kitâbah), dan tanpa metode eklektik tidak mungkin semua kemahiran bahasa akan dikuasai oleh siswa.

\section{Rancangan Metode Intiqâiiyyah (Eklektik)}

\section{Materi Ajar Bahasa Arab}

Jika kita amati suatu materi ajar bahasa terdiri atas (1) topik materi ajar dan (2) desainnya yang menggambarkan kegiatan pembelajarannya. Topik materi ajar bahasa Arab yang efektif adalah topik-topik yang komunikatif dan kontekstual tentang tema keseharian, keagamaan, iptek, dan kepribadian. (Lundeto, diunduh Rabu, 21 Februari 2018).

\section{Desain Pembelajaran}

Desain pembelajaran bahasa Arab terdiri dari (Lundeto, diunduh Rabu, 21 Februari 2018).

a. Keterampilan Mendengar dan Berbicara (Istimâ"-Kalâm)

1) Teks Percakapan yang komunikatif dan kontekstual/atau bentuk CD

2) Mufradât

3) Tadrîbât (Pelatihan)

4) Al'ab lughawiyah (permainan bahasa)

5) Wâjib (Tugas)

b. Keterampilan Membaca dan Menulis (Qirâ"ah-Kitâbah)

1) Teks bacaan yang komunikatif, pragmatik, dan kontekstual

2) Mufradât

3) Contoh-contoh teks yang struktural, komunikatif, dan kontekstual

4) Penjelasan dan kesimpulan (oleh pebelajar atau pengajar)

5) Latihan membaca

6) Wâjib (Tugas)

\section{Langkah-Langkah Pembelajaran}

Seperti apa yang telah dipaparkan di atas bahwasannya metode eklektik ini paling tidak ada dua model metode dalam metode eklektik ini, salah satunya yaitu metode fungsional. Menurut Mahmud Kamil Al-Naqoh (1985 : 112) langkah-langkah pembelajaran dengan metode fungsional antara lain sebagai berikut:

a. Guru menyampaikan kosa kata baru dalam kalimat sempurna yang disampaikan secara lisan, dengan menggunaka media visual atau audio, atau audio-visual sekaligus, atau peragaan dan lain sebagainya. Pada tahap ini, siswa mulai fokus 
mendengarkan kalimat yang asing bagi mereka dengan menggunakan indra pendengaran.

b. Guru mengulangi penyampaian kalimat tadi dengan pelafalan yang benar (sebagai model untuk ditirukan). Pada tahap ini guru harus berupaya agar siswanya benarbenar memahami konteks kalimat yang diajarkannya (melalui bantuan medi), lalu melatih pengucapannya baik secara bersama-sama maupun secara individu.

c. Guru menuliskan kalimat yang diucapkan tadi di papan tulis, agar siswa dapat melihat bentuk tulisannya dan membacanya dalam hati melalui penglihatannya.

d. Guru mengulangi pengucapan kalimat dan mulai menyampaikan beberapa pertanyaan sederhana seputar kalimat yang diajarkan, diawali dengan pertanyaan yang paling mudah, untuk mengecek tingkat pemahaman siswa. Kalau ada siswa yang belum bisa menjawab pertanyaan-pertanyaan yang disampaikan, menurut ukuran metode ini, guru dianggap belum berhasil menyampaikan pelajaran. Oleh karena itu, ia harus mengulanginya. Kalau guru sudah merasa yakin bahwa semua siswanya dapat menjawab pertanyaan-pertanyaan yang disampaikan dengan pelafalan yang benar, baru bisa melangkah ke bagian berikutnya. Tahap ini, mungkin menghabiskan 20 menit atau lebih. Setelah itu, guru meminta siswa untuk membuka dan membaca materi yang sudah disampaikan secara lisan. (Lundeto, diunduh Rabu, 21 Februari 2018.).

\section{Kelebihan dan Kekurangan Metode Eklektik (Thariqah Intiqaiyyah)}

Pada metode eklektik ini berusaha memadukan kelebihan-kelebihan pada metode sebelumnya sehingga dapat menutupi kekurangan-kekurangan metode sebelumnya. Meskipun begitu, metode eklektika ini tidak menutup kemungkinan masih terdapat kekurangan yang harus diatasi, sebagaimana yang dikatakan oleh Fachrurrozi dan Mahyuddin (2010 : 167) bahwasannya "Metode ini bisa menjadi metode yang ideal apabila didukung oleh penguasaan guru secara memadai terhadap berbagai macam metode, sehingga dapat mengambil secara tepat segi-segi kekuatan dari setiap metode dan menyesuaikannya dengan kebutuhan program pengajaran yang ditanganinya, kemudian menerapkannya secara proporsional." Sebaliknya, metode ini bisa menjadi metode "seadanya" atau metode "semau guru", apabila pemilihannya hanya berdasarkan "selera guru", atau atas dasar "mana yang paling enak dan paling mudah" bagi guru, artinya pemilihan bukan didasarkan pada 
pertimbangan yang bertanggung jawab. Bila demikian halnya, maka yang terjadi adalah ketidakmenentuan".

Maksud dan esensi paparan di atas tidak jauh berbeda dengan apa yang diredaksikan oleh Hermawan (2011:199) bahwasannya penggunaan metode ini nampaknya menuntut adanya guru segala bisa dan enerjik (M.F. Baradja, 1990:43).

\section{METODE PENELITIAN}

Metode penelitian yang diterapkan dalam penelitian ini adalah metode eksperimen menggunakan rancangan kelompok kontrol acak. Variabel faktorial yang mempengaruhi adalah metode pembelajaran pada bahasa Arab. Hasil belajar bahasa Arab digunakan untuk mengetahui keterampilan atau kemampuan pembelajaran Bahasa Arab siswa. Pada kelas eksperimen, metode intiqâiyyah sebagai metode eksperimen, dan metode konvensional sebagai metode kontrol di kelas kontrol. Populasinya adalah kelas VII MTs Ma'had Hadits Al-Junaidiyah Biru Bone sebanyak 3 (Tiga) rombongan belajar dan sampelnya adalah dua rombongan belajar atau kelas. Satu kelas atau rombel terdiri dari 2225 siswa dan dari setiap kelas sampel yang mengembalikan angket yang dikirimkan untuk orang tua siswa sekitar 20 siswa dari masing-mesing rombel/kelas. Ujicoba dilaksanakan selama satu semester tahun pelajaran berlangsung.

\section{HASIL DAN PEMBAHASAN}

\section{Deskripsi Data}

Berdasarkan hasil identifikasi data yang telah dilakukan oleh peneliti, berikut disajikan rangkuman hasil analisisnya:

Tabel 2. Komposisi Rata-Rata Skor Hasil Belajar Bahasa Siswa berdasarkan Jenis Metode Pembelajaran

\begin{tabular}{cc}
\hline \multicolumn{2}{c}{ Metode Pembelajaran (A) } \\
\hline Initiqaiyyah (A1) & Konvensional (A2) \\
\hline$n=20$ & $n=20$ \\
$X=78$ & $X=67,2$ \\
\hline
\end{tabular}

Penelitian ini menguji tentang pengaruh metode pembelajaran terhadap hasilbelajar bahasa Arab siswa kelas VII MTs Ma'had Hadits Al-Junaidiyah Biru Bone 2017/2018. Data dikumpulkan dengan menggunakan instrumen hasil belajar bahasa Arab siswa berupa tes bentuk objektive yang telah divalidasi. Guna memberikan gambaran umum 
mengenai data, maka dilakukan dengan menggunakan statistik deskriptif untuk menentukan harga maksimum, minimum, rentang, simpangan baku dan varians, dan ukuran gejala pusat seperti rerata (mean), nilai tengah (median), nilai yang sering muncul (modus) yang dirangkum dalam satu tabel.

Data disajikan dalam bentuk daftar distribusi frekuensi serta histogram. Perhitungan validitas instrumen penelitian menggunakan bantuan komputer program SPSS For Windows 15.0 dan Microsoft Excel, dan reliabilitas tes hasil belajar menggunakan rumus KR-20, sedangkan statistik inferensial digunakan dalam uji normalitas dan homogenitas.

\section{Data tentang Hasil Belajar bahasa Arab Siswa yang diajar dengan menggunakan Metode Intiqâiyyah (A1)}

Skor yang diperoleh sebagai berikut: skor maksimal 100 dan skor minimal 60, rentang skor adalah 38, banyak kelas 6, panjang kelas 7, simpangan baku 9.177, varians 84,210, reratanya 79,72, median 80, dan modus 75, 90 dan 100 besar skor yang hampir sama antara harga rerata, median, dan modus mengindikasikan bahwa sebaran skor hasil belajar bahasa Arab berdistribusi normal. Skor empirik Hasil Belajar bahasa Arab Siswa yang diajar dengan menggunakan Metode Intiqâiyyah disajikan dalam tabel distribusi frekuensi, maka hasilnya pada tabel berikut:

Tabel 3. Hasil Belajar Bahasa Arab Siswa MTs Ma'had Hadits AlJunaidiyah Biru Bone yang diberi Metode Intiqiaiyyah

\begin{tabular}{ccccc}
\hline & Nilai & \multicolumn{3}{c}{ Frekuensi } \\
\cline { 3 - 5 } & & Absolut & Relatif $(\%)$ & Kumulatif \\
\hline $60-66$ & 63 & 2 & 8 & 2 \\
$67-73$ & 70 & 3 & 12 & 5 \\
$74-80$ & 77 & 9 & 36 & 14 \\
$81-87$ & 84 & 7 & 28 & 21 \\
$88-94$ & 91 & 1 & 4 & 22 \\
$95-101$ & 98 & 3 & 12 & 25 \\
\hline Jumlah & & 25 & 100 \\
\hline
\end{tabular}

Dari tabel 3 di atas, berdasarkan pengelompokan skor tersebut dari 20 responden dapat diketahui responden terbanyak memiliki skor antara 66-74.

Selanjutnya, apabila penyebaran skor variable hasil belajar bahasa Arab ditampilkan pada histogram dan poligon, maka hasilnya sebagai berikut: 


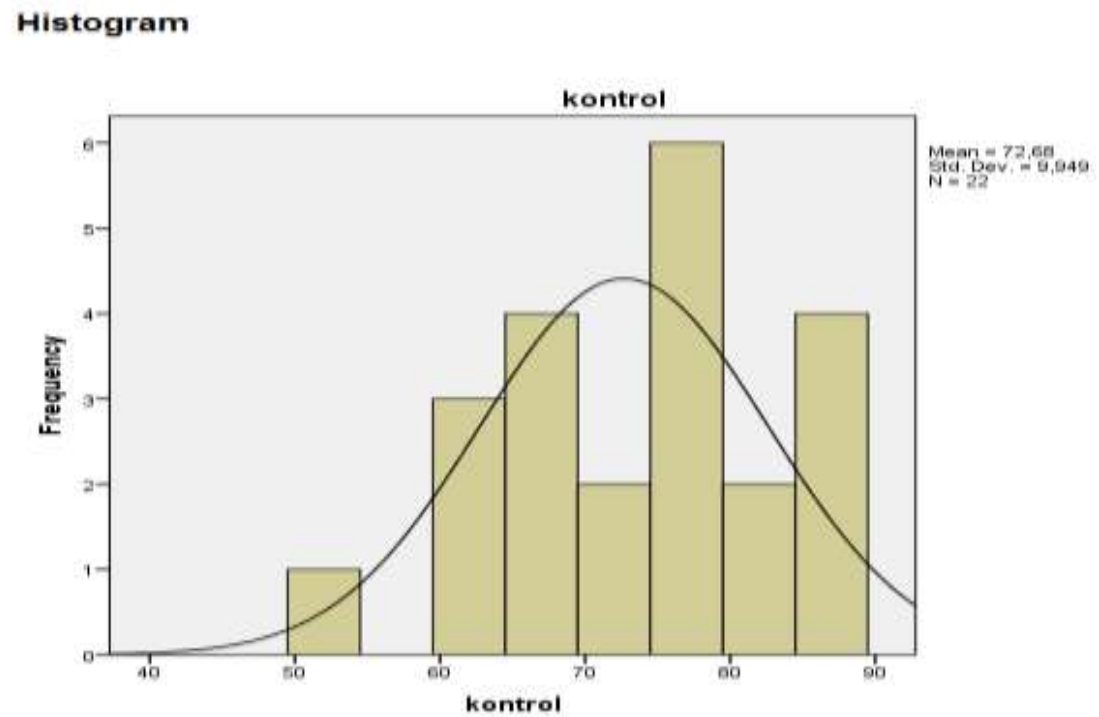

Gambar 1. Histogram dan Poligon Sor Hasil Belajar Bahasa Arab

Kolom vertikal pada histogram menunjukan berapa kali hasil belajar bahasa Arab siswa muncul dalam kumpulan data, garis horizontal menggambarkan hasil belajar bahasa Arab siswa. Tampak kolom vertikal tertinggi berada antara 66-74. hal ini menunjukan bahwa hasil belajar bahasa Arab siswa yang paling sering muncul berada pada kisaran tersebut yaitu pada frekuensi 5.

\section{Data tentang Hasil Belajar Bahasa Arab Siswa yang Diajar dengan Menggunakan Metode Konvensional/Aqw'id dan Terjemah (A2)}

Skor yang diperoleh sebagai berikut: skor maksimal 89 dan skor minimal 52, rentang skor adalah 37, banyak kelas 6, panjang kelas 7, simpangan baku, 9.949 varians 98.989, reratanya 72.68, median 75 , dan modus 75 besar skor yang hampir sama antara harga rerata, median dan modus mengindikasikan bahwa sebaran skor hasil belajar bahasa Arab berdistribusi normal. Skor empirik hasil belajar bahasa Arab Siswa yang diajar dengan menggunakan Metode Intiqaiyyah disajikan dalam tabel distribusi frekuensi, maka hasilnya pada tabel 4 berikut: 
Tabel 4. Hasil Belajar Bahasa Arab Siswa MTs Ma'had Hadits AlJunaidiyah Biru Bone yang diberi Metode Konvensional (Qawa'id dan Terjemah)

\begin{tabular}{ccccc}
\hline & Nilai & \multicolumn{3}{c}{ Frekuensi } \\
\cline { 3 - 5 } & & Absolut & Relatif (\%) & Kumulatif \\
\hline $52-58$ & 55 & 1 & 4.5 & 1 \\
$59-65$ & 62 & 7 & 31.85 & 8 \\
$66-72$ & 69 & 2 & 9.09 & 10 \\
$73-79$ & 76 & 6 & 27.28 & 16 \\
$80-86$ & 83 & 4 & 18.19 & 20 \\
$87-93$ & 90 & 2 & 9.09 & 22 \\
\hline Jumlah & & 20 & 100 & \\
\hline
\end{tabular}

Dari tabel di atas, meyoritas responden sokrnya berada antara 67 - 78 dan 79-90 yaitu sebanyak 12 atau $60 \%$. Responden dengan skor berada di bawah rata-rata sebanyak 8 siswa atau $40 \%$ dan responden dengan skor berada di atas rerata sebanyak 12 atau 60\%. Kesimpulan bahwa hasil belajar bahasa Arab siswa VII MTs Ma'had Hadits Al-Junaidiyah Biru Bone yang diajar dengan metode konvensional (Qawâ"id dan Terjemah) termasuk kategori rendah Paparan Hasil belajar bahasa Arab siswa kelas VII MTs Ma'had Hadits Al-Junaidiyah Biru Bone yang diajar dengan metode konvensional lebih diperjelas dengan dengan sajian histogram dan poligon frekuensi dalam gambar di bawah ini:

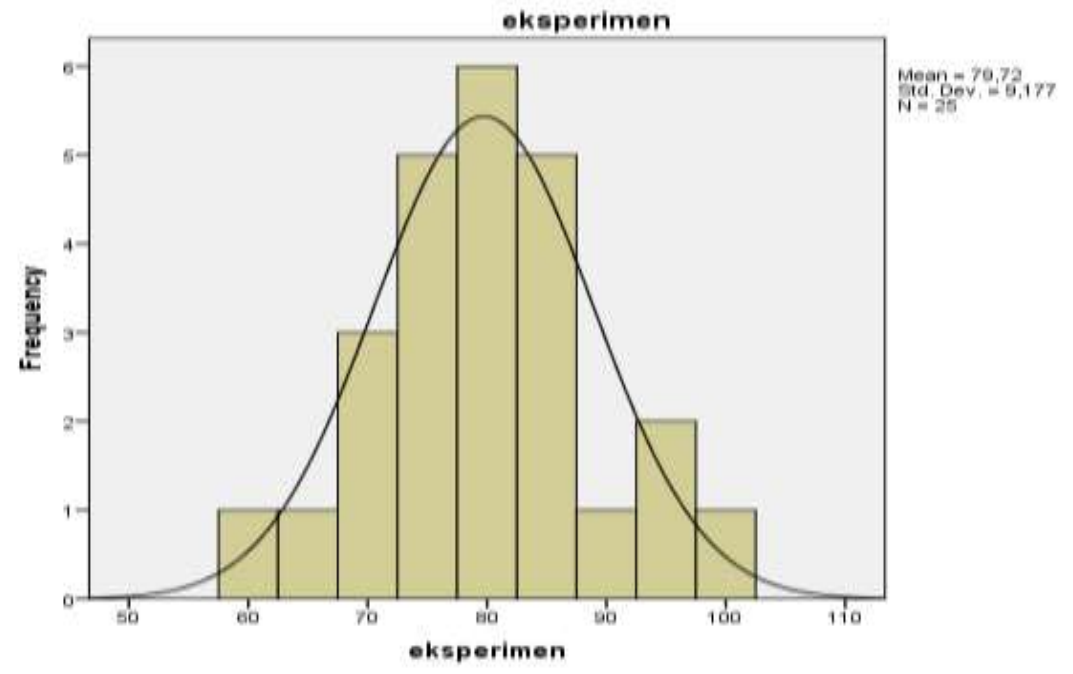

Gambar 2. Histogram dan Poligon Skor Hasil Belajar Bahasa Arab

Kolom vertikal pada histogram menunjukan berapa kali hasil belajar bahasa Arab siswa muncul dalam kumpulan data, garis horizontal menggambarkan hasil belajar matematika siswa. Tampak kolom vertikal tertinggi berada antara 67-78 dan 79-90. Hal 
ini menunjukan bahwa hasil belajar bahasa Arab siswa yang paling sering muncul berada pada kisaran tersebut yaitu pada frekuensi 12 .

\section{Pengujian Hipotesis}

Hasil belajar bahasa Arab siswa yang diberi metode intiqâiyyah lebih tinggi daripada siswa yang diberi metode konvensional yakni metode qawâ"id dan terjemah yang diterapkan di Kelas VII MTs Ma'had Hadits Al-Junaidiyah Biru Bone, Hipotesis statistik yang dapat dibuat adalah sebagai berikut:

$$
\begin{aligned}
& H_{0}: \mu_{10}=\mu_{20} \\
& H_{1}: \mu_{10}>\mu_{20}
\end{aligned}
$$

Hasil analisis variansi menyimpulkan bahwa varians antar kolom sangat signifikan karena Fhitung $=6,82>$ Ftabel $=4,11$ pada taraf signifikansi 0,05. Berdasarkan hasil perhitungan di atas maka dapat disimpulkan bahwa hipotesis teruji kebenarannya, yaitu Hasil belajar bahasa Arab siswa yang diberi metode intiqâiyyah lebih tinggi daripada siswa yang diberi metode konvensional/ Qawâ"id dan Terjemah. Hasil pengujian menunjukkan perbedaan, oleh karena itu dilanjutkan dengan uji Tukey sebagai uji lanjut untuk mengetahui metode mana yang lebih unggul. Perhitungan uiji Tukey menunjukkan bahwa hasil belajar bahasa Arab siswa yang diajar dengan menggunakan metode intiqaiyyah lebih tinggi dari daripada diajar dengan menggunakan metode konvensional/ Qawâ"id dan Terjemah dengan hasil uji lanjut menggunakan uji Tukey yakni

$$
Q_{\text {hitung }}=10,47>Q_{\text {tabel }}=5,02
$$

pada taraf signifikansi 0,01, berarti hasil belajar bahasa Arab siswa VII MTs Ma'had Hadits Al-Junaidiyah Biru Bone yang diajar dengan menggunakan metode intiqâiyyah lebih unggul daripada siswa yang diajar menggunakan metode konvensional/ Qawâ"id dan Terjemah.

\section{Interpretasi Hasil Penelitian}

Berdasarkan hasil perhitungan dan pengujian hipotesis menunjukkan hipotesisdapat diterima. Hasil penelitian menunjukkan bahwa: Pertama, hasil belajar bahasa Arab siswa yang diberi metode intiqâiyyah lebih tinggi daripada siswa yang diberi metode konvensional/ Qawâ"id dan Terjemah. Hal tersebut disebabkan oleh karena pembelajaran dengan metode intiqâiyyah lebih mengarah kepada dinamisme pembelajaran. Pembelajaran 
tidak monoton, sebaliknya fleksibel dan menyenangkan bagi semua anak yang belajar bahasa Arab.

Sementara pembelajaran dengan menggunakan metode konvensional/Qawâ"id dan Terjemah cenderung menjenuhkan bagi rata-rata siswa. Pembelajaran menjadi kaku, stagnan, dan tidak menarik bagi siswa. Pada gilirannya hasil belajar bahasa Arab siswa lebih rendah jika dibandingkan dengan pembelajaran menggunakan metode intiqâiyyah.

Alasan metode ini tepat dalam pembelajaran bahasa, karena: Pertama, Setiap metode pengajaran bahasa asing memiliki kelebihan masing-masing, dan bisa kita mengambil kebaikan-kebaikannya. Kedua, Tidak ada metode yang sempurna dan tidak ada metode yang jelek, akan tetapi setiap metode pembelajaran bahasa asing ada kelebihan dan ada kekurangan dan kesemuanya memiliki alasan dan dalil masing- masing.

Ketiga, Akan lebih baik jika kita berpandangan bahwa satu metode hanya akan sempurna jika kita menyandingkannya dengan metode lain. Bukan beranggapan bahwa antara satu metode dengan lainnya saling bertentangan, Keempat, Tidak pernah ditemukan ada satu metode pun yang sesuai atau cocok terhadap semua tujuan, siswa, guru, dan semua jenis kurikulum pengajaran bahasa asing.

Hasil penelitian ini sesuai dengan teori yang dikemukakan oleh al-Khûlî yang menyatakan metode Intiqâiyyah hadir karena ketidakpuasan atas metode pembelajaran bahasa asing yang sudah ada; metode qawâ"id dan terjemah, metode langsung dan metode sam"iyyah syafawiyyah, metode yang mengambil aspek-aspek yang tepat dalam metode sebelumnya (Unsi, 2017:102-119).

\section{PENUTUP}

Dari uraian tersebut dapat disimpulkan bahwa hasil belajar siswa yang menggunkan metode intiqâiyyah lebih tinggi dibandingkan siswa yang diajar dengan menggunakan metode konvensional. Peneliti memberikan saran-saran berdasarkan hasil penelitian yakni pertama, hendaknya para ahli dan pemerhati bahasa Arab, yang sampai saat ini pengembangannya sangat lemah lebih berusaha mengembangkan metode-metode pembelajaran bahasa Arab yang produktif, sehingga ada usaha-usaha nyata dan tepat sasaran dalam menyelesaikan segala problem yang selalu muncul di lapangan, kedua, hendaknya MTs Ma'had Hadits Al-Junaidiyah Biru Bone, dapat menjadikan penelitian ini sebagai feedback dengan melakukan pelatiahan-pelatihan metode pembelajaran khusus bagi guru bahasa Arab untuk memperbaiki diri dengan kebijakan-kebijakan yang 
menunjang, karena bagi Madrasah termasuk di dalamnya MTs Ma'had Hadits AlJunaidiyah Biru Bone keberadaan bahasa Arab adalah trademark, jika bukan dengan bahasa Arab maka Madrasah bukanlah Madrasah Ibtidaiyah namun Sekolah Dasar.

Ada beberapa saran yang perlu ditindaklanjuti pimpinan MTs Ma'had Hadits AlJunaidiyah Biru Bone dan madrasah serta lembaga pendidikan yang membelajarkan bahasa Arab setingkat MTs lainnya agar terus memberikan dukungan dan dorongan kepada guru untuk mengikuti pendidikan dan kegiatan ilmiah lainnya terutama yang berkaitan peningkatan metode pembelajaran bahasa Arab. Guru bahasa Arab di MTs Ma'had Hadits Al-Junaidiyah Biru Bone dan madrasah serta lembaga pendidikan yang membelajarkan bahasa Arab setingkat MTs lainnya agar terus meningkatkan kemampuan menerapkan metode eklektik dalam pembelajaran bahasa Arab agar pembelajaran bahasa Arab sukses sesuai dengan tujuan yang telah dirumuskan.

\section{DAFTAR PUSTAKA}

al-Khûlî, Muhammad. Alî. Asâlîb Tadrîs al-Lughah al-,,Arabiyyah, al-Mamlakah alArabiyyah al-Sưûudiyyah: Maktabah al-Farzadaq, t.t.

al-Anati, Walid. 2009. Kitab Nun wa al-Qalam Dirasah Lisaniyah Tarbaniyah li Ta'lim alArabiyyah li al-Nathiqin bi Ghairiha, Jami'ah al-Batra, al-Urdun.

Ayatullah. 2016. Penerapan Metode Eklektik pada Pembelajaran Bahasa Arab Siswa Kelas VI SDIT Anak Sholeh Mataram. Jurnal Palapa, Vol. 4, No. 1.

Budiono. 2005. Kamus Lengkap Bahasa Indonesia. Surabaya: Karya Agung.

Djaafar, Tengku Zahara. 2001. Kontribusi Strategi Pembelajaran terhadap Hasil Belajar. Padang: Fakultas Ilmu Pendidikan Universitas Negeri Padang.

Ibrahim, Nurdin. 2001. Hasil Belajar Siswa SLTP Terbuka Tanjung Sari Sumedang Jawa Barat. Jurnal Pendidikan dan Kebudayaan, No.031, Tahun ke-7.

Lundeto, Adri. Pengembangan Metode Pengajaran Bahasa Arab, http://jurnaliqro.files. wordpress .com/2008/08/04-adri-37-47.pdf, diunduh Rabu, 21 Oktober 2009.

M.F, Baradja. 1990. Kapita Selekta Pengajaran Bahasa, Malang : Penerbit IKIP Malang. Parera, Jos Daniel. Linguistik Edukasional. Jakarta: Erlangga.

Muhbib, Abdul Wahab. 2008. Metode Penelitian dan Pembelajaran Nahwu: Studi Teori Linguistik Tammam Hassan. Jakarta: SPs UIN Syarif Hidayatullah Jakarta.

Peraturan Menteri Agama Republik Indonesia Nomor 2 Tahun 2008 Tentang Standar Kompetensi Lulusan Dan Standar Isi Pendidikan Agama Islam Dan Bahasa Arab Di 
Madrasah. Lembaran Negara Republik Indonesia Tahun 2008. Bab VI: Standar Kompetensi (SK) Dan Kompetensi Dasar (KD) Mata Pelajaran Pendidikan Agama Islam Dan Bahasa Arab Madrasah Ibtidaiyah.

Rahman, Anwar Abd. 2011. Pengajaran Bahasa Arab dengan Metode Eklektik", Jurnal Adabiyah, Vol. 11, No. 1.

Rifa'i, Ahmad. 2015. Implementasi Thariqah al-Intiqaiyyah (Metode Eklektik) pada Pembelajaran Bahasa Arab di MTsN Kediri 1. Jurnal Realita, Vol. 13, No. 2.

Rivai, Veithzal. 2002. Prestasi Hasil Belajar Peserta Program MM untuk Mata Kuliah Manajemen Keuangan. Jurnal Pendidikan dan Kebudayaan. No. 038 Tahun ke-8.

Shaleh, Abdul Rahman dan Muhbib, Abdul Wahab. 2004. Psikologi Suatu Pengantar Dalam Persfektif Islam. Jakarta: Kencana.

Unsi, Baiq Tuhfatul. 2017. Optimalisasi Pembelajaran Bahasa Arab melalui Model Pembelajaran Komunikatif-Eklektik. Murobbi: Jurnal Ilmu Pendidikan, Vol. 1, No. 1. 